IMPORTANT: THIS IS A PRE-PRINT VERSION. THE FINAL VERSION CAN BE PURCHASED FROM ROUTLEDGE.

Chapter 11:

\title{
Constructing gender and sexuality in the EFL classroom in Poland: Textbook construction and classroom negotiation?
}

Joanna Pawelczyk and Łukasz Pakuła

\begin{abstract}
Poland, as a young conservative democracy, is witnessing an unprecedented amount of public debate where 'gender' and 'sexuality' figure prominently. Both, however, tend to be perceived as foreign imports and thus fiercely contested. Consequently, the role of English as a Foreign Language (EFL) materials as well as teachers as potential mediators of markedly different Anglophone socio-politics is of paramount importance.
\end{abstract}

What is more, the only Polish research examining the portrayal of women in EFL materials is that by Jaworski (1986), who exposed the abundance of sexism in EFL textbooks available in Poland at that time. Regrettably, 'sexuality' as a culturally (but not linguistically) important identity category was not addressed or recognised in the broad Polish educational context until 2012 (Świerszcz 2012).

This chapter reports on two studies conducted as part of the research project entitled "Investigating Gender and Sexuality in the ESL classroom: Raising publishers', teachers' and students' awareness". The aim of the first study was to qualitatively scrutinize the discursive and multimodal construction of gender, gender relations, and sexuality in two leading illustrated Primary School EFL textbooks in Poland, along with the accompanying workbooks and teacher's books. To this end the analytical methods of Feminist Critical Discourse Analysis (Fairclough 1989; Lazar 2005, 2014), Multimodal Discourse Analysis (see e.g. Giaschi 2000; Guo 2004; 0’Halloran 2004; Kress and Van Leeuwen 2006) and the concept of critical heteronormativity (Motschenbacher 2010, 2011) were utilized. The analyses focused on the representation of the social roles of men and women, boys and girls in EFL materials. They also demonstrated different textual manifestations of heteronormativity.

'Gender critical points' (Sunderland et al. 2002) - identified in the first study were drawn on in the second study. We also extended Sunderland et al.'s (2002) concept by introducing the notion of 'gender-emerging points', which we believe enriches the analytical apparatus by highlighting the dynamic character of classroom interactions and thus the central role of teachers. Here we used audio-recorded primary school classroom interactions to demonstrate how the identified 'gender critical points' are addressed and how 'gender-emerging points' surface and/or are made (ir-)relevant in the classroom setting. Thus the analysis focused on gendered 'talk around the text' emerging in teacher-student interactions to explore negotiation, challenge and/or rejection and 'uptake' of gender roles and discourse. To this end methods and insights from critical linguistic analysis were used along with Sunderland's (this volume) agenda for future research on gender representation in foreign language textbooks. 
Keywords: EFL, gender, sexuality, Poland, CDA, Multimodal Discourse Analysis, hidden sexuality and gender curriculum

\section{Introduction: 'I only teach English'}

In our conversations with EFL teachers (both male and female) whom we asked to participate in the Project ${ }^{1}$ we often heard comments such as 'oh, I only teach English, there is nothing related to gender in my classes'. Such a comment aptly summarizes EFL teachers' lack of awareness of the various ways in which gender primarily (but also other social categories) is (un-)consciously drawn on in the act of teaching and learning.

Learning (and teaching) of any subject is always social and it cannot be separated from explicit and implicit learning (and teaching) about society (Menard-Warwick et al. $2014)^{2}$. No language (including that produced in the foreign language learning environment) is ever produced in a social vacuum, as even the grammatical structures commonly practiced in the EFL classroom are almost always peopled with individuals who are recognizably men or women. Thus EFL teachers are in fact constantly involved in teaching about society, which to a great extent entails teaching about gender roles and may involve reinforcing, for instance, the subordinate role of girls and women and the dominant role of boys and men (Freeman and McElhinny 1996: 261). Menard-Warwick et al. (2014) regard classroom interaction, literacy (teaching and learning organized around textbooks, worksheets, etc.) as well as language learning (encompassing both interaction and literacy as learners navigate how to engage with other speakers and with texts) as the most salient topics in research literature on language and gender in educational contexts. Textbooks - as Menard-Warwick et al. (2014: 477) claim- "are a popular site for inquiry because they are the mainstay of education and can have a great impact on students and society at large". Sunderland (2014) asserts that language textbooks are important for the study of language, gender

\footnotetext{
${ }^{1}$ We are referring here to the Project that the authors have been involved in at the time of writing the article. The project is entitled "Investigating Gender and Sexuality in the ESL classroom: Raising publishers', teachers' and students' awareness" and funded by the British Council within the English Language Teaching Research Partnerships scheme.

2 Martỉnez-Roldán (2005) for instance shows how by participating in a literature discussion group, students explored their understanding of gender: "They thoroughly questioned the gendered worlds around them and in books. This study shows how literacy learning and gender development may go hand in hand" (Menard-Warwick et al. 2014: 480).
} 
and language education as they constitute textual forms of (gender) representations as well as an 'epistemological site' for gender and language study. EFL textbooks seem the most prototypical as well as the most researched of language learning materials (Sunderland 1994: 55).

\section{Gender and sexuality in textbooks: Overview of the findings and current research}

Most of the research into the foreign language textbooks with regard to gender representations carried out in the 1970s and 1980s was content or linguistic oriented with some aspects of visual analysis and focused on the text-as-product (Sunderland et al. 2002: 225). In this sense textbook content was treated as non-negotiable and the fact that learners may have (potentially different) responses to the textbooks' content was hardly considered. As Sunderland et al. (2002: 223) describe, the findings relating to the (earlier) portrayals of women and girls in English language textbooks can be aptly described with such terms as 'Exclusion', 'Subordination', 'Distortion' and 'Degradation' (for specific research findings see Talansky 1986; Porecca 1984; Schmitz 1975; Pascoe 1989). Textbooks were thus at that time conceived of as very powerful resources with the potential to convey non-negotiable portrayals of men and women.

Sunderland (2014) points to more recent studies' greater gender awareness, the publishers' 'Guidelines for inclusive language' as well as more studies of EFL books used outside Anglophone countries. Menard-Warwick et al. (2014), for example, state that content analyses have appeared more recently in some other national contexts, e.g., Brazil (Oliveira 2008) or Iran (Ghorbani 2009). Furthermore, Jones and colleagues (1997), who examined three EFL textbooks (Headway Intermediate, Hotline Intermediate and Look Ahead 2) to analyze specifically the language of dialogues, found an encouraging level of gender fairness, achieved through the creation of gender balance in social and occupational roles. Yet as Sunderland observes, except for corpus studies (e.g., Mukundan and Nimehchisalem 2008; Yuen et al. 2008) there has been little change in research methodology. Furthermore, female 'invisibility' can still be (occasionally) found (e.g. Lee and Collins 2009; Barton and Sakwa 2012) but there are also some exceptions, e.g., Pihlaja (2008) or Healy (2009). Finally, there seem to be more equal numbers of female and male characters (Sunderland 2014). 
All in all, as Sunderland (2014) asserts, the studies into gender representation in foreign language textbooks need to be more nuanced, e.g., the question of textbook sub-genres or 'frequencies' in terms of types (e.g., Mary Wilson) and tokens, i.e., references to the character (e.g., how many occurrences of Mary Wilson) should be taken on board. They also should address the issue of multimodality as well sexuality or at least heteronormativity (Sunderland 2014). This is particularly important as patriarchy and sexism are assuming newer, and sometimes not so clearly recognizable forms (Lazar 2014: 195) and the educational context (including EFL) is one of the sites where their 'indirect but no less grievous forms' (Mills 2008) should be identified. Similarly, MenardWarwick et al. (2014: 486) call for renewed attention to gender inequities in educational research cautioning against the assumption that male dominance is a thing of the past. Commenting on the consequences of the exposure of children to the sexist portrayals in the ESL textbooks, Porecca (1984: 723) states the following:

however serious the consequences of such textbook bias may be for college ESL students, they must be infinitely more so for younger ESL learners, whose limited experience gives them little basis for questioning what they read and who generally tend to trust the printed word more than adults do ... children exposed to such sex biases can very quickly and easily integrate them into their own value systems.

In this chapter, we will be analysing the two EFL textbooks addressed to very young EFL learners in Poland. Porecca's hypothesis (see above) has been corroborated by DePalma and Atkinson's (2010) whose observations indicate that homophobic and transphobic attitudes are uncritically internalised by children at a very early age. They also notice that reproduction of most narrow and stereotypical images with regard to sexuality and gender has been corroborated by a number of prior studies (e.g. Blaise 2005; Renold 2005). This might be due to little reflexivity and critical thinking skills but also hidden sexual and gender curricula (Miceli 2006) present in all courses - something that can be found in our data as well.

If we accept that discourse is always concurrently socially representational and socially constitutive (Fairclough 2001), the gender portrayals found in the early analyses can be seen to have the potential to legitimate the relative 'Exclusion' and 'Subordination' of female characters and 'Distortion' of gender relations in general - depending, inter alia, 
on how they are used and talked about in class. Indeed although critical evaluation of gender representation in language textbooks is vital (see Porecca's 1984 quotation above concerning the consequences of young EFL learners' exposure to gender bias in language textbooks), Sunderland (2000: 154) concludes that "looking at the text alone may be a fruitless endeavor". Thus what needs closer investigation is how teachers deal with 'gendered texts', e.g., what is done with those representations in class. Interaction including interaction with the text - after all is a basic tool for social life and making meaning in and out of classroom (Menard-Warwick et al. 2014: 472). Consequently, since texts can be used in various ways, it is more important to examine how teachers and students engage with texts (see Martỉnez-Roldán 2005). Sunderland et al. (2002) use the term 'talk-around-the text' (a concept from literacy studies) to explicate how the language teacher in his/her 'read aloud' role talks about gender in textbooks.

Explorations of 'talk-around-the text' in terms of gender representation should focus on those textbooks in which gender is somehow evident - what Sunderland et al. (2002: 231) call a 'gender critical point':

...critical in the sense that, having reached such a point in the textbook, the teacher would then have to do something about the particular gender representation ${ }^{3}$ (even if that something was 'playing it by the book', or ignoring it).

Gender representation extends to a myriad of portrayals of women, men, boys, girls and gender relations more widely, progressive, traditional, or both. What is of interest is how the texts are 'consumed' (Fairclough 1992) in terms of 'teacher treatment' but also in teacher-student and student-student interactions. What this chapter adds to this perspective is that teachers sometimes tend to 'gender' a text which has originally been (intended as) non-gendered thus 'gender-emerging points' appear spontaneously in the course of classroom interaction. Gender in this case tends to be used as a resource that Polish teachers draw on to facilitate some aspects of foreign language teaching (in the case of the current chapter -- grammar and lexis). This reliance on gender as facilitator points to its rigidness and binarity for femininity and masculinity are treated as bounded practices not to be transgressed.

\footnotetext{
3 Italics in the original.
} 


\section{What's sexuality got to do with it? Exploring marginalised identities in EFL education}

Should we expect same-sex affection and same-sex families with offspring 4 to feature in EFL textbooks? In line with Gray's (2013: 43) argument that heterosexuality is "strategically privileged" in the capitalist reality, is the observation that EFL practitioners and students are exposed to extreme cases of "monosexualising tendencies" (Nelson 2006). Textbooks aimed at the global market include exclusively heterosexual identities, which uncontested by the teacher lead to the feeling of alienation on the part of non-heterosexual students thus "hinder[ing] their language learning process" (Gray 2013; Nelson 2007). Surely, it would be naïve to expect a radical change with respect to the range of sexualities covered in such materials (Sunderland, this volume). Thus we agree with Sunderland (this volume) that the analysis of the representation and construction of sexuality should not look at the absent nonheterosexualities, but rather should aim to challenge the degrees of heteronormativity. Heteronormativity, a less subtle form of heterosexism (see Queen 2006), is implied here as "the view that institutionalised heterosexuality constitutes the standard for legitimate and expected social and sexual relations" (Ingraham 2006: 199). With particular reference to language use, Motschenbacher, one of the proponents of critical heteronormativity research, understands it as

[...] all linguistic mechanisms that lead to heterosexuality being perceived as the naturalized norm, which in turn is to be destabilised and confronted with nonheteronormative alternatives. 'Non-heteronormative' has two relevant readings, depending on which component is taken to be the focal point of the negotiation, i.e. non heteronormative (pertaining to sexualities except heterosexualities) or non-heteronormative (pertaining to non-normative heterosexualities). (Motschenbacher 2010: 11) ${ }^{5}$

\footnotetext{
${ }^{4}$ Families of choice are still a controversial issue in many countries (cf. Mizielińska and Stasińska 2013).

5 See also Motschenbacher (2011) for an informative discussion of Queer Linguistics and critical heteronormativity research.
} 
This perspective has been gaining momentum for some time now with numerous studies exploring heteronormative practices within the classroom setting (e.g., Rothing 2008; Liddicoat 2009). In the realm of EFL, Nelson's work (1999, 2006, 2007, 2009, 2012) deserves serious consideration. Nelson, in her pioneering work, utilises the conceptual apparatus of Queer Theory (see Sullivan 2003) to explore the classroom discourse and opportunities for a diversity-inclusive environment; Morrish and Saunston (2007) have made similar attempts in the academia. Nelson urges us to critically reflect on our heteronormative habitual practices, which might result in uncovering new routes to language learning. This can be arrived at, among others, by using lesbian and gay themes to explore divergent cultural meanings and meaningmaking practices and challenging the heterosexual matrix (see Butler 1990). Examining the life history narratives of queer residents who are part of the same local communities as the language learners could, in turn, provide a learning experience that students could personally relate to (Nelson 2007).

This inclusion-oriented campaign in foreign language learning is of paramount importance as "students whose voices are not being acknowledged in the classroom may lose their desire to learn the language or may even engage in passive resistance to classroom practices and curriculum demands" (Pavlenko 2004: 59). Nelson's (1999, 2007) answer to this postulate is to recognise the lack of one universal sexual identity of a given student and cast a polyphonic look at students within the classroom setting. As Queer Theory (Sullivan 2003) embraces the view of a dynamic and situational construction of gender and sexual identities, the teacher is not viewed in terms of an unquestioned authority, but rather as a discussion facilitator and moderator. Stemming from that is Nelson's recommendation not to opt for gay and lesbian inclusion but rather "sexual-identity inquiry" as this better fits the role teachers are to fulfil (Nelson 2007: 70). This approach has had enthusiastic responses on part of other researchers, for example, De Vincenti et al. (2007) and O'Mochain (2006) have obtained positive results when attempting to incorporate nonheteronormative themes into their classroom practices $^{6}$.

\footnotetext{
${ }^{6}$ Ripley et al.'s (2012) study cautions us against the perceptions of non-heterosexual contents of courses. Exploring the perceived versus actual ratio of gay and straight themes used in the context of the classroom, they show that even gay-friendly students viewed gay themes as more frequent than straight ones, even though the actual ration was 1:2 respectively.
} 
The 'queer pedagogies' introduced by Cynthia Nelson could be inscribed in a more elaborate educational project, i.e. 'critical pedagogies' (Norton 2008; Monchinski 2008). Advocates of this approach to teaching (and learning) draw special attention to power structures (potentially) rendering students powerless with the aim of making them aware of these power structures, voicing and challenging them ${ }^{7}$.

\section{"The ideology of gender": Demonised gender and closeted sexuality}

We believe that Poland as a geopolitical reality deserves special attention as it markedly differs with respect to the treatment of the concepts of 'gender' and 'sexuality' from the majority of the European countries by treating both of these terms as highly tabooed. This state-of-affairs might be traced to 'moral panics' triggered by the Polish Catholic Church along with the right-wing politicians.

Some of the most prominent Catholic Church representatives see 'gender' as their main enemy. Importantly, gender here is viewed not as an analytical tool but rather an umbrella term encapsulating a number of negatively-loaded concepts and ideas - from the perspective of the Catholic Church -- such as the sexualisation of children, introducing same-sex marriage, radical feminism, relativisation of stereotypical gender roles and finally paedophilia ${ }^{8}$. Understood as such, 'gender' has been termed by the Catholic Church as the 'ideology of gender' so as to enable any other 'immoral' item that could be added to this list. This phrase has been introduced into the public and media discourses and even successfully travelled to the academia9. This coinage has been granted the stamp of approval by a parliamentary panel, whose sole ambition is to eradicate the 'ideology of gender' from the Polish public life,. At least for the past six

\footnotetext{
${ }^{7}$ See Norton and Toohey (2004) for a more thorough treatment of this approach when applied to language learning.

8 Paedophilia is very often mentioned as a result of one's homosexuality especially in the context of samesex parents' adoptions. Here, the widely discredited research by Mark Regenerus is adduced as a (quasi) argumentum ad verecundiam and thus a tool for scientific grounding and legitimisation of the discrimination of lesbian and gay people.

${ }^{9}$ Some right-wing inclined academics gave "anti-gender" talks whose controversial contents are clearly expressed in their titles: "Gender, jak się przed tym bronić" (Gender, how to defend ourselves against it?) or "Gender - dewastacja człowieka i rodziny" (Gender - destruction of the human and family).
} 
months, a vast number of newspaper articles and weekly magazine supplements ${ }^{10}$ warning Polish society of the disastrous effects of passively incorporating 'the ideology of gender' have been published. Not surprisingly, then, some politicians and academics have gone on to claim that this ideological concept should be deemed worse than Nazism or communism ${ }^{11}$.

Sexuality, in turn, is a concept which means many things to many people (e.g. Weeks 2010; Jackson and Scott 2010; Rogers and Rogers 2001) and thus our use of the concept needs to be addressed here ${ }^{12}$. We are committed to the broader definition of this key term acknowledging its complexity by seeing it as a sum of such components as sexual desires, sexual health, and identities. Public and institutional talk on this understanding of 'sexuality' is highly tabooed in the Polish society. Sexual education is virtually nonexistent in educational settings whilst parents seem incapable of handling sexualityrelated discussions with their children (cf. Izdebski 2012). Furthermore, in schools knowledge about human sexuality is communicated during the non-compulsory Wychowanie do życia w rodzinie (Family life education) ${ }^{13}$, a course most often taught by instructors with a conservative outlook on life ${ }^{14}$ and highly influenced by Christian ideology. The outcome of this situation is easily foreseeable: research suggests that there is a huge deficit in the awareness of human sexuality in adolescents and adults (Izdebski 2012: 720) ${ }^{15}$. It goes without saying that the predominance of stereotypes over factual medical, sociological, and psychological knowledge results in othering those whose sexuality does not conform to the heteronorm (e.g. Krzemiński 2008).

\section{Breaking the silence: Pioneering research in the broader Polish educational context}

\footnotetext{
10 With such titles as "Gender kontra rodzina" (Gender versus family) (source: http://www.wsieci.pl/gender-kontra-rodzina-dodatek-specjalny-pnews-738.html)

11 The level of absurd, some might claim, has been reached when an anti-gender online course has been launched by one of the priests campaigning against the "ideology of gender" and - another concept worthy of mention - i.e. "homoideology".

12 Cameron and Kulick (2003: X) pose the fundamental question "what do we mean by 'sexuality'?" to conclude that, in the field of language and sexuality, the concept in question is used synonymously with sexual orientation.

13 All translations from Polish are ours, unless indicated otherwise.

14 Obtaining qualifications to teach this subject is relatively unproblematic (Izdebski 2012).

15 Poor knowledge of human sexuality and numerous stereotypical misconceptions are one of the causes of marginalising nonheterosexual Poles by still denying them the right to enter any kind of institutionalised partnerships (e.g. Mizielińska and Stasińska 2013).
} 
While research on gender (discrimination) in education has had a long tradition now (Menard-Warwick et al. 2014; Kehily 2002; Carr and Pauwels 2006; Kopciewicz 2011), insights into sexuality are still relatively poor. This seems to be due to the fact that bringing up the subject of sexuality is likely to bring about fierce opposition in any school community (and beyond) (Meyer 2010: 58). Consequently, silencing issues regarding marginalization, stigmatization, and bullying of certain social groups has had disastrous effect on individuals' lives, suicide being the most dramatic one (Rosario et al. 2012; Agostinone-Wilson 2010; Świerszcz 2012; Horn et al. 2009; Miceli 2006).

To date, there have been only a few inquiries into the issue of equality at various levels of education in Poland ${ }^{16}$. Moreover, most of them did not explicitly focus on sexuality per se. The "School of open-mindedness report" (Żukowski 2004) foregrounds ethnic and religious minorities, but devotes only one chapter to the question of sexuality and gender in the context of Family Life Education (FLE). The report criticizes the Ministry of Education for legitimizing the Catholic Church bias in the FLE curricula which enables the textbooks to smuggle quasi-scientific data -- among others -- about the use of condoms and sexual identities which runs counter to current research. Moreover, as yet another report reveals, FLE textbooks impose one national model of masculinity and femininity which is seen to be fundamental to the values of the Polish culture (Abramowicz 2011: 229). These findings have been corroborated in comprehensive and in-depth research undertaken by a team of experts looking at biology, FLE, and civics textbooks from the perspectives of sexology, gender studies, sexual education, and clinical psychology (Kochanowski et al. 2013). The textbooks examined generally silence the issue of LGBTQ people but if they take it up, they do so in a very biased way. The most obvious flaw is treating heterosexuality as the norm but also instances of conflating homosexuality and bisexuality, pathologising homosexuality, and mentions of reparative therapy as one of the cures for homosexuality have been detected. The plethora of factual errors in textbooks coupled with the omission of

\footnotetext{
16 Abroad situation seems somehow more optimistic with more projects and attention devoted to the issue (Franck 2002; Gorski and Goodman 2011; Hickman 2012; Kehily 2002; Toomey et al. 2012).
} 
discussions relating to sexuality is a serious failing that the Polish educational system needs to face ${ }^{17}$ (Świerszcz 2012).

In light of the socio-political climate in Poland, scarce research on the construction of gender and sexuality comes as no surprise. Miceli (2006) reports on a similar situation in the USA, where sexual education has been present for some time now, yet many Catholic and Christian fundamentalists have sought to limit or eradicate sexual education from schools with the view to protecting their children against the "dangers" of sexuality and "reinstalling sexual morality to the culture" (Miceli 2006: 363). In the next section we narrow the perspective down to the EFL context in Poland.

\section{Three decades of silencing gender from the EFL practice in Poland}

Elsewhere we looked at the EFL classroom dynamics and materials from the perspective of power distribution and imbalances (Pawelczyk et al. 2014). We highlighted the fact that all participants in the learning process are active 'vehicles of power'. In fact,

[...] language teaching and learning has often had associations with concentrations of power where [...] people have sought to learn languages to gain access to power and to resist oppression, and people have tried to teach languages so as to gain control or extend influence over others. (Crookes 2009: 595)

The realisation that power was an issue in critical EFL research has, however, not been given proper attention in the Polish context. In his analysis, Jaworski (1986) discusses two different perspectives: language of women and androcentrism in language-use. Jaworski detected three types of sexist tactics, i.e. omission of women, negative stereotyping (also of men), and negative contrast with men. Jaworski (1986) also points to the heavy use of the "generic" man/he and the rare and inconsistent use of his or her. An interesting observation was made with regard to the occasional English to Polish translations provided in the analysed textbooks. As it turns out, despite the fact

17 Cultivated homophobia results in 'recursive marginalisation' (Bogetić 2013) whereby nonheteronormative students bully other nonheteronormative students for their gender nonconforming behaviour (Świerszcz 2012). 
that it is customary to supply Polish translations in the masculine gender ${ }^{18}$, translations of some adjectives, e.g. conceited, breach this tradition and receive feminine gender (P. zarozumiała). This can be seen as a tactic of gendering personality features, and attributing stereotypically negative ones to women only.

Apart from neglecting issues of power, Jaworski's study is not informed by guidelines designed by other (feminist) reviewers (e.g. Schmitz 1984). Despite these reservations, it did introduce interesting points not present in the-then literature. He is critical of classifying certain depictions as sexist and asks for detailed and objective criteria for such classifications. This is in contrast to a criticism levelled at some feminist EFL materials reviewers of cherry picking, resulting in impressionistic judgements. Furthermore, an important issue is raised: men also experience stereotyping, and this fact was given less importance in other studies. Jaworski also cautions us against unrealistic expectations of EFL textbooks by saying that they

[...] cannot be blamed for being the sole instigators of sexism in students' use of the target language. However, there is no reason why FLM [foreign language materials ] should serve to reinforce and justify sexist usage of the target language by foreign students. (Jaworski 1986: 87)

Taking into account the timeframe and communist reality at the time of writing this book, we should see these words as innovative and anticipating further developments and refinement of this field of enquiry.

\section{The Study}

In this chapter we examine two EFL textbooks commonly used in the primary schools in Poland to identify the social positionings of women (girls) and men (boys). Here we will also apply the concept of heteronormativity to reveal and better understand a specific set of family and social relations explicitly and implicitly promoted in the investigated textbooks.

For the purpose of the analysis we selected two EFL textbooks used in Polish primary schools. The first of them, Starland was published by the Express Publishing.

\footnotetext{
${ }^{18}$ See more on gender in the Polish language in Kiełkiewicz-Janowiak and Pawelczyk (2014).
} 
We have scrutinized Part 3 of the textbook (first Polish edition 2010). Starland has been officially approved by the Polish Ministry of National Education on the basis of the positive recommendations of foreign language teaching experts. Starland 3 has been partially adjusted to the local Polish context in terms of the occasional reliance on Polish and the reference to some elements of the Polish culture. Thus in the Student's Book we can encounter Polish names of the dialogue characters as well as reference to some Polish cities. At the end of the book there is a bilingual (English-Polish) word list. In the Workbook, on the other hand, Polish is the dominant language of instruction: all task instructions are given in Polish. Similarly, all the grammar rules are explained in Polish (e.g., the distinction between the use of Past Simple and Present Perfect) and there are some translation exercises as well.

The other textbook, New English Zone 3, was published by Oxford University Press and underwent partial adjustment to cater for the needs of Polish primary school learners. Each English instruction to an exercise is accompanied by a Polish translation. Also, all grammar explanations and various explanation and hint boxes are in Polish. In contrast with Starland, however, no in-depth content adaptations were made. Generally, the whole book contents could be described as Anglocentric as the reality presented is mostly British. Similarly to Starland, there is also an English-Polish word list.

Next, drawing on the concept of 'gender critical points' (Sunderland et al. 2002) as well as gendered 'talk around the text' we examine how gender and/or sexuality are oriented to and/or made relevant by teachers and students in the audio-recorded classroom interactions. The analysis will also point to teachers' 'gendering' of the originally non-gendered texts (gender-emerging points) and will reveal a variety of ways in which texts are consumed in a gendered manner.

\section{Gender and sexuality in the EFL classroom in Poland}

In what follows a qualitative scrutiny of the discursive and multimodal construction of gender, gender relations, and sexuality in the two EFL primary school textbooks (readings, dialogues and grammar/vocabulary exercises) and their accompanying workbooks will be presented drawing on methods and insights of (Feminist) Critical Discourse Analysis (Fairclough 1989; Lazar 2014), Multimodal Discourse Analysis (see e.g. Giaschi 2000; Guo 2004; O’Halloran 2004; Kress and Van Leeuwen 2006) and the 
concept of critical heteronormativity (Motschenbacher 2010, 2011). Additionally selected Teacher's Books's instructions will be analyzed to examine if teachers are instructed (or not) to draw on the category of gender in (co-)constructing theirs and their students' classroom performances.

\section{Starland 3}

\section{Readings}

We found 27 readings of various length in the textbook and 14 of them feature human protagonist(s). There are main female characters in 2 of them, 8 male protagonists and in 4 of the readings there are both male and female protagonists. A qualitative examination of the readings reveals quite stereotypical and normative functioning of the male protagonists. The main male characters are agents who are typically on the go, active and involved in extreme sports. For example, there is Roy, a forest ranger who survived seven lightning strikes and Tom, a teenager who is the best diver in Britain. These texts are accompanied by visuals of active protagonists (Giaschi 2000) thus enhancing the verbal content of the text (Unsworth and Cléirigh 2011). As far as the female protagonists are concerned, the first text discusses friendship among teenage girls with a detailed description of the physical characteristics of one of the girls accompanied by two smiling girlfriends positioned close to one another and looking together at the computer screen, while the second one features Bethany Hamilton who is a surfer who survived a terrible shark attack. Bethany is presented visually (next to the text) as involved in the act of surfing. Finally, the text focusing on both male and female protagonists draws on the gendered division of labour. Thus the boy is involved in action while the girl is described in terms of her appearance. This text on 'teen tribes' features a skater boy from the UK and manba girls from Japan (i.e., girls with extreme fashion style) whose distinguishing quality is their appearance. The texts are accompanied by images of the boy who is skating and the girl colourfully dressed which enhance the verbal content of the texts. All in all the readings tend to construct a gendered world with communal girls and agentive boys with only a few exceptions of more progressive gender roles.

\section{Dialogues}


We identified 8 dialogues in the textbook. 6 of them feature male and female characters, in 1 of them there are only male heroes while in 1 there are only female characters. 3 of the dialogues were initiated by males and 3 of them by females. We would like to give more attention to the three dialogues in which either gendered discourse patterns are followed or expected gendered behaviour is contested. In a dialogue featuring Sam and Mary, Sam is commenting on the female character's outfit (including complimenting) relying on authoritative discourse patterns devoid of any mitigation and hedging thus enacting domination (Lazar 2014). In the exchange comprising seven turns, Sam takes the powerful role of questioner and evaluates Mary's choice of clothes. In another dialogue, Jenny is giving John some medical advice overall following the normative assumption of women as advice-givers. Thus she overtly comments on John's unwell appearance and advises on the steps to be taken. Finally in the dialogue between Wendy and Sam, it is Wendy who is instructing Sam how to use memory stick and thus she is positioned in the role of an expert. As for the visual aspects, the dialogues either lack illustration or are accompanied by the images of the 'issues' that constitute the core problem in the dialogues, e.g., computer screen shots next to the memory stick dialogue are presented. Only in one case, two boys in snorkelling equipment accompany the dialogue between two male friends about weekend plans. Overall, the dialogues seem to move away from the dominant gender views by incorporating both male and female voices as well as by allowing the dialogue characters to draw both on symbolic femininity and symbolic masculinity ${ }^{19}$ in enacting their social roles.

\section{Grammar and vocabulary exercises}

Another sub-genre that we scrutinized were grammar and lexical exercises (Sunderland 2014). Close investigation of this sub-genre revealed that it constitutes one of the main sites of the gendered world in the textbooks. We identified 4 main types of exercises in which gendered content is extensively used/relied on in the process of teaching grammar and vocabulary.

\section{Pattern 1: Fill-in exercises}

\footnotetext{
19 i.e., cultural and social expectations of how women and men (should) act and speak (see Pawelczyk and Graf 2011).
} 
This type of exercise constitutes the dominant format in the analyzed textbook. Thus the young EFL learners need to fill in the gaps in the already constructed sentence with the correct grammatical form (be it a grammatical tense, an article or an adjective form). The 'already given' constructs the world in very gendered and heteronormative terms. Thus 'dads work', 'mums make cakes', 'Steve trains to be a pilot' and 'she was cooking while he was working'. Such a gendered division can be observed both in the student's book as well as in workbook. A variation in this pattern can be observed when every example in the exercise is accompanied by an image that enhances the gendered verbal content (Giaschi 2000). For example in one of the exercises on the use of articles students learn that "Julie is a nurse. She works at ... hospital". This sentence is accompanied by a female nurse. Thus the content of the sentence is enhanced by the accompanying image (see Unsworth and Cléirigh 2011). In other words, the gendered substance of the grammatical exercise is reinforced by the images.

\section{Pattern 2: Matching exercises}

We have also identified a number of exercises in which learners are asked to match a lexical item with the appropriate picture. In this type of an exercise, students are asked to match names of the professions (verbal) with job performers who are either male or female (image) or the sports discipline with a person (male, female) who is performing this sport in the provided images. Gender is very much drawn on in this type of exercise as the images portray the stereotypical (assumed) job performer. Thus for instance, the airline pilot is male while the model is female. In the case of the sport matching exercise (8 different sports) there are only men presented in the pictures in very active positions. These lexical matching exercises reinforce - and in the long run, by repeating this pattern, legitimize the view - that there are male and female domains both in professional life as well as in the choice of sports.

\section{Pattern 3: Sentence writing (with a male protagonist)}

Here we are referring to a type of a grammar exercise in which learners practice a grammatical construction (e.g., Present perfect tense) by constructing sentences around the same protagonist (in a sense creating a mini narrative). This protagonist tends to be male (e.g., John) who is typically involved in a very active endeavour.

Pattern 4: Non-gendered verbal prompts to be used with images with a male/female (performer) 
There are many exercises in which students are provided with a list of activities (e.g., making a salad, playing tennis) which then need to be used as captions under images showing males or females involved in the listed activities. Thus we can see a female preparing a salad in the picture and two men playing tennis. Images used in this type of an exercise (of males or females) impose the gendered interpretation/reading on the activities. Consequently practising lexical items in this type of an exercise entails rehearsing and reinforcing gendered and heteronormative assumptions about humans. To sum up, the grammar/lexical exercises with their predominately gendered construal of the world implicitly and progressively socialize the young EFL learners into the world in which conservative gender relations prevail.

\section{Interaction with the text}

As asserted by Sunderland (e.g., Sunderland et al. 2002) and others (see MenardWarwick et al. 2014) what should be closely investigated is the teacher's treatment of gendered texts. In other words - according to Sunderland et al. (2002) - gender-critical points need to be identified in the analyzed texts and then teacher's handling of these salient points should be detailed by the researcher during their observations of classroom interactions. There are various scenarios emerging here as teachers in their 'read aloud' roles can subscribe to the views promoted by the textbook or, on the contrary challenge them and propose new reading(s). Teachers can also actively prompt students to voice their opinions on the views projected in the textbook or, on the contrary, silence them. Teachers play a vital role in how the texts will be dealt with in classroom interactions and thus how the potential gendered content will be consumed. This handling has consequences for all the EFL learners but particularly for young EFL students (see Porreca 1984; DePalma and Atkinson 2010) whose still limited foreign language skills and general trust in teachers may prevent them from resisting these imposed readings.

The numerous gender-critical points in Starland 3 discussed above were not explicitly taken up by the teacher during the classes that we observed and audio-recorded. This is to say that the teacher followed all the texts in the form they were originally designed with no additional comments/elaboration that could resist, challenge or refocus the covered texts even though there were numerous opportunities for this. For example, in the case of matching the name of the profession with the male or female the teacher 
could ask whether a female could be a pilot too and then, depending on the elicited answers, give examples of women who are/have been successful pilots.

What we have observed however, was rather teacher's gendering of the texts (including grammar and lexical exercises) that have originally been designed as non-gendered. We consider these as cases of 'gender-emerging points'. We would like to discuss now two examples of such gendering. During one of the classes that we recorded the students were discussing the use of conditional structures. In the textbook there is an exercise devoted to this structure in which students have to complete the sentences starting with "If I were an animal. I'd be ...; If I were a flower, I'd be...; If I were a colour, I'd be ...; If I were a food item, I'd be .... Starland 3 Teacher's Book advises the teacher to explain the task and allow some time for its completion and then ask students to compare their answers to find potential similarities. The teacher in our study however, refocused this exercise entirely by putting two sentences on the board with a clear instruction that one of them is to be completed by girls only (If I were a flower, I'd be...) and the other one by boys only (If I were a car, I'd be...). Thus what we observed is the teacher's drawing on the category of gender to (potentially) facilitate the process of learning conditional structures. Yet in this way she/he also further contributes to reinforcing in the young EFL learners a sense of the binary division of the world based on gender.

In another exercise children were asked to say which TV programmes they enjoy watching and were offered a list of programmes (10 items) ranging from the news to soap operas. The Teacher's Book instructs the teacher to elicit which types of programmes students enjoy by asking questions. The teacher indeed asked the questions to students yet boys and girls were asked about different programmes. The boys were asked about sports programmes, quiz shows and the news while girls about soap operas and cartoons. Then the teacher asked the students to ask one another similar questions. Interestingly the pattern set up by the teacher was followed by the students. Thus boys were asked about the news and sports while girls about sitcoms and soap operas. We could observe in this exercise again how the originally non-gendered lexical task was gendered by the teacher. Regrettably by using only some of the vocabulary items from a ten-item pool, students did not get to practice all the lexical items that the exercise aimed at. What they in fact practiced though was the activity of watching TV as a gendered practice. 


\section{New English Zone 3}

\section{Readings}

The textbook contains 16 readings in two sections per each unit. One reading exercise in each unit is usually followed by comprehension and related listening exercises while the second reading is a showcase project that students are supposed to model their own projects on.

As far as the first type of readings is concerned, 3 readings deserve special attention as they exemplify a powerful tool by which certain ideologies are smuggled in to learning inconspicuously. A five-paragraph text on robots replacing humans in daily household chores constitutes a seemingly neutral and degendered content. It is only at the last sentence that this impression is dispelled, when we read: "But the food won't taste like Mum's cooking!". By this means the entire reading, which might have been an interesting starting point on the household labour division, propagates the stereotypical casting of women into the role of a family cook. Yet another example of this type is a reading from unit five where a text on Melissa relocating for a year from England to Australia. Apart from Melissa's impressions and reflections on the experience, her parent's occupations are provided: her mother is a nurse whilst her father's a university teacher. Again, a clearly visible hierarchy is constructed whereby women occupy less prestigious and powerful positions. An interesting case of two competing discourses was noticed in a reading on shopping. Here, the text presented against a pink background and accompanied by photographs of female twins and a girl during shopping, talks of Kelly, who loves shopping and Helen, who does not. While the former character is a spendthrift, the latter presents a more sensible attitude towards money by saving it.

As for the second type of readings - projects - our attention was drawn to two factors: projects' (imagined) authorship and contents of some texts. Every text is supplied with a photograph of one of the three characters-authors - Matthew, Jack or Rebecca - who tell us what kind of project they completed. A stark contrast can be noticed with respect to the numbers of females and males as the ratio is 2:6 respectively. Turning to the content of the texts, we notice recurring stereotypes again. While projects on 'Australia' or 'English across the world', are relatively neutral, those on transportation (Jack) and shopping (Rebecca) are not. An interesting project, done by 
Matthew, is the one on families in the UK. The text is divided into two sections. The first one deals with a realistic depiction of the types of families in the UK at present. Large families from 30 years ago are represented sentimentally, whereas the text concludes that about $30 \%$ of families are now single-parent families. We witness, however, a dramatic shift in the quality and type of the narrative in the second part: Phil's family is presented, again, with the mother fulfilling the communal role while the father is the breadwinner. Recalling Sunderland's (this volume) words that same-sex parenting should not be expected to enter EFL textbooks in the foreseeable future, it needs to be born in mind that the UK was one of the precursors of introducing same-sex partnerships and in 2014 - marriages (cf. Bachmann 2011). This leads us to conclude that the representation of stereotypical gender roles can be correlated with a high degree of heteronormativity.

\section{Dialogues}

Altogether 16 dialogues accompanied by photographs were identified, two per unit in the book. These include the same set of protagonists throughout: the Turnbull's and Mathew Turnbull's classmates, i.e. Jack and Rebecca. Matthew's character is definitely the central one, around which all the dialogues revolve. His central role is already markedly noticeable in the revision unit, which precedes all 8 units of the book, as well as by placing his image accompanied by his utterances in 8 out of 16 dialogues. Therefore, Matthew is not only foregrounded but also constructed as the active male commentator on all the developments within the home and schooling environments. As far as the male/female ratio is concerned, single-sex dialogues occur only twice: two males' (Matthew and Jack) discussion at a swimming pool and two females' (Rebecca and a shop assistant) conversation on clothes. Therefore a subtle stereotyping already takes place in these two short exchanges. All in all, 24 male and 23 female characters were singled out. Turning to a qualitative analysis, it is crucial to notice the exclusively familial role of the mother character. She cooks, asks male characters to dinner (when they play football), regulates her daughter's time spent after school, assigns household chores to her offspring, tricks them into helping her in the kitchen. These observations strongly resonate with the pervasive stereotype of a woman as carer. Other females also suffer from stereotypical construal. Female verbosity is clearly evoked when Monica attempts to explain herself for arriving home later than her mother expected: she met a friend for a drink and "forgot the time". Another common stereotype, that of a woman 
lacking special orientation skills, is evoked when Matthew, Rebecca and Jack are on a London trip looking for Madame Tussaud's. To do justice to the authors of the textbook, however, it needs to be pointed out that Rebecca, who is simultaneously constructed as a moaner, after initial ridicules of her topographic suggestions, proves to be right in the end. Such conflicting representations are not common, though. Apart from moaning, female characters often feel unwell -Lucy and Rebecca who complain about that. On the other hand, male characters actively pursue sporting hobbies, show initiative and offer ironic comments on the behaviour of the females.

\section{Grammar and lexical exercises}

Unlike in Starland, this textbook does not offer so many gendered grammar exercises. The case of the accompanying workbook is radically different though as most of the exercises seem to draw on reading and dialogues featuring characters who preserve their stereotypical gendered roles. These exercises invite students to comply with the stereotypes, at least for the sake of successfully (and correctly) completing their tasks.

\section{Teacher's book (TB)}

The introduction part of the teacher's book sets forward challenging and praiseworthy aims. Among others, the 'culture zone' component of each unit (one containing the second reading as described above) is meant to "promote an understanding of cultural diversity as well as positive view of these countries" (p.5). The dialogue part, along with the accompanying photographs, is meant to "provide insight into British life, helping students to develop their cultural awareness" (p.4). Is this corroborated in the hints that the authors of the TB provide on the following pages? Sadly, not. In fact, the perpetuation of stereotypes is exaggerated by making suggestions that students, when re-enacting dialogues, make sure that Mum is annoyed (at least two times), the children are dismayed at mother's requests, a female shop assistant needs to be polite, and Rebecca should sound tired; while Matthew is "determined to get what he wants". Our reservations pertain to other proposed activities as well. An alternative, one could say subversive, dialogue re-enactment is suggested by an exchange between Mum and Monica, who is late from school. The teacher hint reads: "[i]f you have a mixed class (boys and girls), get boys to work with boys and girls with girls. Choose a pair of boys to read a dialogue". Later on, the teacher is advised to ask a pair of boys to read the dialogue and girls to serve as the evaluators. Next, girls do the same. The teacher is faced 
with the question, which presumably should be addressed by the students themselves: “[c]an they do it better?".

In terms of sexuality, heteronormativity is prevalent. The suggestions for activities accompanying the 'Family life in the UK' project, ask students to compare the 'British' family life with Polish. A serious reservation arises when the teacher is advised to ask students to model their own family life description project on Phil's. Imposing the norm, in this case the classical heterosexual family, where gender roles are anything but progressive, is then pervasive in the textbook under examination.

\section{Classroom interaction}

The following is a transcript from a question and answer session following a listening task on the division of household chores. In the recording, Ewan, states that his mother does most of the housework. Having completed the listening task, students are invited to answer the following question "who does most of the housework?".

[T=teacher and Ss= students; [ ] = overlapping speech]

\begin{tabular}{l} 
Household chores - division of labour \\
\hline 1 T: Who does most of the housework? \\
2 Ss: Mom! \\
3 T: Mom, yes. What about your family? \\
4 Ss: Mom! \\
5 T: Mom? Mom? \\
6 S: Mom \\
7 S: Dad! \\
8 S: Grandma \\
9 T: haha, yes, of course, you've got grandma! So, grandma, yes. What about your \\
10 family? \\
11 S: [dad \\
12 S: Mom] \\
13 T: Mom? And your? \\
14 S: Mom \\
15 T: of course[mom \\
16 S: \\
17 T: Next question number who? \\
18 S: Dad \\
19 T: Dad in your family, really? \\
20 S: yhy \\
21 T: wow that's something different
\end{tabular}

Within this interaction a traditional division of labour within a household is clearly enforced. Most students responding with the, presumably, expected answer that the 
mother is the household manager, were praised for saying so. However, when one of the male students responds that it is the father who takes over these duties in his family, the teacher asks for reassurance that the message she received was the intended one. Thus dad's role in household chores is problematised. Following that, she constructs this as untypical thus diverging from the expected norm where mothers typically 'do most of the housework'. It is also interesting to notice how the teacher powerfully manages the interaction by inserting interactional items (e.g., of course, yes) that regulate and reinforce the traditional gender order.

\section{Conclusions}

The analysis of the two EFL textbooks at the primary school level revealed the discourse of conservative gender relations and gender imbalance that is occasionally interspersed with a discourse of progressive gender relations. Heteronormativity and heterosexism were found to be the defining feature of numerous activities, identities and communities constructed in the textbooks.

Sunderland (this volume) asserts that different sub-genres have different potentials. We see grammatical and lexical exercises as the specific sub-genre of textbooks, which can potentially contain much encoded (fixed) gendered representations, and thus has much potential to function as significant socializing agent in the process of gender role acquisition in the context of EFL. The gendered and heteronormative content is not typically taken up by teachers as their main focus is students' correct choice of a grammatical structure or a lexical item. Thus this 'already given' gendered and heteronormative content is not oriented to by teachers who - as they claim- remain preoccupied with grammar itself. We see teachers' gendering practices as their own way of facilitating the process of teaching grammar. This fixedness and non-negotiability of gendered and heteronormative content in the case of grammatical/lexical exercises is particularly detrimental to very young EFL learners (see Porecca 1984; Sunderland 2014; DePalma and Atkinson 2010) who not only tend to take such portrayals for granted but may importantly integrate them into their own life narratives. A shift in focus from 'gender-critical points' to 'gender-emerging points' was also highlighted, which shows that a lot of gendering work going on the EFL classroom can not be anticipated prior to a given classroom interaction. This calls for more 
research into this area as well as more critical awareness (see Lazar 2014) on the side of teachers.

All in all, the analysed textbooks tend to construct the gendered world not only in the readings or dialogues but also in grammar and vocabulary exercises. The textual construction - as the analysis evinced -- tends to be further reinforced by the teachers who typically completely accept the texts' gendered content during classroom interactions. This is to say that there is hardly any negotiation of the stereotypical gender portrayals during EFL classroom interactions, while their reinforcement permeates classroom practice. Given the central role of the teacher in how texts (and exercises) are consumed and that teaching of any subject is always social, we call for EFL teachers' more critical reflexivity about what kind of realities and identities they construct in the EFL classroom.

\section{References}

Abramowicz, Marta (ed.). 2011. Wielka Nieobecna [The Great Absentee]. Warszawa: Towarzystwo Edukacji Antydyskryminacyjnej.

Agostinone-Wilson, Faith. 2010. Marxism and Education beyond Identity: Sexuality and Schooling. Palgrave Macmillan.

Bachmann, Ingo. 2011. 'Civil partnership - "Gay marriage in all but name”: A corpusdriven analysis of discourses of same-sex relationships in the UK Parliament', Corpora 6, 1: 77-105.

Barton, Amanda and Lydia Namatende Sakwa. 2012. 'The Representation of Gender in English Textbooks in Uganda', Pedagogy, Culture and Society 20, 2: 173-190.

Blaise, Mindy. 2005. Playing It Straight: Uncovering Gender Discourse in the Early Childhood Classroom. New York: Routledge.

Bogetić, Ksenija. 2013. 'Normal straight gays: Lexical collocations and ideologies of masculinity in personal ads of Serbian gay teenagers', Gender and Language 7, 3: 333-367.

Butler, Judith. 1990. Gender Trouble. Feminism and the Subversion of Identity. New York: Routledge.

Cameron, Deborah and Don Kulick. 2003. Language and Sexuality. Cambridge: Cambridge University Press. 
Carr, Jo and Anne Pauwels. 2006. Boys and foreign language learning. Houndmills, Basingstoke: Palgrave Macmillan.

Crookes, Graham. 2009. 'Radical language teaching', in: Michael H. Long and Catherine J. Doughty (eds.), The Handbook of Language Teaching. Oxford: Wiley, 595-609.

DePalma, Renée and Elizabeth Atkinson. 2010. 'The nature of institutional heteronormativity in primary schools and practice-based responses', Teaching and Teacher Education 26, 8: 1669-1676.

De Vincenti Gloria, Angela Giovanangeli and Rowena Ward. 2007. 'The queer stopover: How queer travels in the language classroom', Electronic Journal of Foreign Language Teaching 4, suppl 1: 58-72.

Fairclough, Norman. 1989. Language and Power. London: Longman.

Fairclough, Norman. 1992. Discourse and Social Change. Cambridge: Polity Press.

Fairclough, Norman. 2001. Language and Power. (Second edition.) New York: Longman.

Franck, Kevin C. 2002. 'Rethinking Homophobia: Interrogating Heteronormativity in an Urban School', Theory \& Research in Social Education 30, 2: 274-286.

Freeman, R. and McElhinny, B. (1996) Language and gender. In: McKay, S. L. and Hornberger, N. H. (eds.) Sociolinguistics and language teaching. Cambridge: Cambridge University Press, p. 218-280.

Ghorbani, Laya. 2009. An investigation of the Manifestation of Sexism in EFL/ESL Textbooks. Institute of Education Sciences.

Giaschi, Peter. 2000. 'Gender positioning in education: A critical image analysis of ESL texts', TESL Canada Journal 18, 1: 32-46.

Gorski, Paul C. and Rachael D. Goodman. 2011. 'Is There a "Hierarchy of Oppression" in U.S. Multicultural Teacher Education Coursework?', Action in Teacher Education 33, 5-6: 455-475.

Gray, John. 2013. 'LGBT Invisibility and Heteronormativity in ELT Materials' , in: John Gray (ed.), Critical Perspectives on Language Teaching Materials. New York, NY: Palgrave Macmillan, 40-63.

Guo, Libo. 2004. 'Multimodality in a biology textbook', in: Kay L O'Halloran (ed.), Multimodal discourse analysis systemic-functional perspectives. London; New York: Continuum.

Hickman, Heather. 2012. 'Handling heteronorativity in high school literature texts', in: Heather Hickman and Brad J. Porfilio (eds.), The New Politics of the Textbook: Problematising the portrayal of marginalized groups in textbooks. Rotterdam: Sense Publishers, 71-85. 
Horn, Stacey S., Joseph G. Kosciw and Stephen T. Russell. 2009. 'New Research on Lesbian, Gay, Bisexual, and Transgender Youth: Studying Lives in Context', Journal of Youth and Adolescence 38, 7: 863-866.

Ingraham, Chrys. 2006. 'One is not born a bride. How weddings regulate heterosexuality.', in: Steven Seidman, Nancy Fischer and Chet Meeks (eds.), Handbook of the New Sexuality Studies. London: Routledge, 197-201.

Izdebski, Zbigniew. 2012. Seksualność Polaków na poczq̨tku XXI wieku. Studium badawcze [Poles' sexuality at the beginning of 21st century. A study.]. Kraków: Wydawnictwo Uniwersytetu Jagiellońskiego.

Jackson, Stevi and Sue Scott. 2010. Theorising Sexuality. Maidenhead: Open University Press.

Jaworski, Adam. 1986. A linguistic picture of women's position in society: a Polish-English contrastive study. Frankfurt am Main: Verlag Peter Lang.

Kehily, Mary Jane. 2002. Sexuality, Gender and Schooling: Shifting Agendas in Social Learning. Routledge.

Kiełkiewicz-Janowiak, Agnieszka and Joanna Pawelczyk. 2014. 'Language and gender research in Poland: An overview', in: Miriam Meyerhoff, Ehrlih Susan and Janet Holmes (eds.), Handbook of language and gender. Oxford: Wiley-Blackwell.

Kochanowski, Jacek, Zbigniew Lew-Starowicz, Robert Kowalczyk and Krzysztof Wąż. 2013. Szkoła milczenia: przegląd treści szkolnych podręczników do biologii, WOS i WDŻR pod kątem przedstawienia w nich problematyki LGBTQ i treści homofobicznych. Toruń: Stowarzyszenie Na Rzecz Lesbijek, Gejów, Osób Biseksualnych, Osób Transpłciowych Oraz Osób Queer [The school of silence: In search of LGBTQ and homophobic contentc in biology and family life education textbooks]. Toruń: Pracownia Różnorodności.

Kopciewicz, Lucyna. 2011. Nauczycielskie ponizanie. Szkolna przemoc wobec dziewcząt [Teachers' humiliating students. Violence against women in schools]. Warszawa: Difin.

Kress, Gunther R and Theo Van Leeuwen. 2006. Reading images: the grammar of visual design. London; New York: Routledge.

Krzemiński, Ireneusz. 2008. Naznaczeni. Mniejszości seksualne w Polsce. Raport 2008. [The marked. Sexual minorities in Poland. 2008 Raport]. Warszawa: Instytut Socjologii Uniwersytetu Warszawskiego.

Lazar, Michelle M. 2005. Feminist critical discourse analysis: gender, power, and ideology in discourse. Houndmills, Basingstoke, Hampshire; New York: Palgrave Macmillan.

Lazar, Michelle M. 2014. 'Feminist Critical Discourse Analysis: Relevance for Current Gender and Language Research', in: Susan Ehrlich, Miriam Meyerhoff and Janet 
Holmes (eds.), The Handbook of Language, Gender, and Sexuality. Oxford: Blackwell Publishing Ltd, 180-199.

Liddicoat, Anthony J. 2009. 'Sexual Identity as Linguistic Failure: Trajectories of Interaction in the Heteronormative Language Classroom', Journal of Language, Identity \& Education 8, 2-3: 191-202.

Martinez-Roldan, Carmen M. 2005. 'Examining Bilingual Children's Gender Ideologies through Critical Discourse Analysis' , Critical Inquiry in Language Studies 2, 3: 157-178.

Menard-Warwick, Julia, Miki Mori and Serena Williams. 2014. 'Language and gender in educational contexts', in: Susan Ehrlich, Miriam Meyerhoff and Janet Holmes (eds.), The Handbook of Language, Gender and Sexuality. Oxford: Wiley-Blackwell, 471-490.

Meyer, Elizabeth J. 2010. Gender and Sexual Diversity in Schools: An Introduction. London: Springer.

Miceli, Melinda S. 2006. 'Schools and the social control of sexuality', in: Steven Seidman, Nancy Fischer and Chet Meeks (eds.), Handbook of the New Sexuality Studies. London: Routledge, 357-364.

Mills, Sara. 2008. Language and Sexism. Cambridge: Cambridge University Press.

Mizielińska, Joanna and Agata Stasińska. 2013. ‘Od „wroga rodziny” do jednej z jej form: Rodziny z wyboru we współczesnym polskim dyskursie prasowym' [From the "enemy of the family" to one of family forms. Families of choice in the contemporary newspaper discourse in Poland] , InterAlia. a Journal of Queer Studies 8: 105-128.

Monchinski, Tony. 2008. Critical Pedagogy and the Everyday Classroom. New York: Springer.

Morrish, Liz and Helen Sauntson. 2007. New perspectives on language and sexual identity. Basingstoke: Palgrave Macmillan.

Motschenbacher, Heiko. 2010. Language, Gender and Sexual Identity: Poststructuralist perspectives. Amsterdam: John Benjamins Publishing Company.

Motschenbacher, Heiko. 2011. 'Taking Queer Linguistics further: sociolinguistics and critical heteronormativity research', International Journal of the Sociology of Language 2011, 212.

Mukundan, Jayakaran. and Vahid Nimehchisalem. 2008. Gender representation in Malaysian Secondary School English Language textbooks. Indonesian Journal of English Language Teaching 4.2, 155-173.

Nelson, Cynthia D. 1999. 'Sexual identities in ESL: Queer theory and classroom inquiry', TESOL Quarterly 33, 3: 371-391. 
Nelson, Cynthia D. 2006. 'Queer Inquiry in Language Education', Journal of Language, Identity \& Education 5, 1: 1-9.

Nelson, Cynthia D. 2007. 'Queer Thinking about Language Teaching', in: Helene DeckeCornill and Laurenz Volkmann (eds.), Gender studies and foreign language teaching. Tübingen: Narr.

Nelson, Cynthia D. 2009. Sexual Identities in English Language Education: Classroom Conversations. New York: Routledge.

Nelson, Cynthia D. 2012. 'Emerging queer epistemologies in studies of "gay"-student discourses', Journal of Language and Sexuality 1, 1: 79-105.

Norton, Bonny. 2008. 'Identity, language learning, and critical pedagogies', in: Nancy H. Hornberger (ed.), Encyclopedia of Language and Education. New York: Springer, 45-57.

Norton, Bonny and Kelleen Toohey (eds.). 2004. Critical pedagogies and language learning. Cambridge: Cambridge University Press.

O’Halloran, Kay L (ed.). 2004. Multimodal discourse analysis systemic-functional perspectives. London; New York: Continuum.

Oliviera, Sara. 2008. "Visual Text, Gender Stereotypes and Language Textbooks.” Trabalhos em Linguistica Aplicada, 47: 91-117.

O'Mochain, Robert. 2006. 'Discussing Gender and Sexuality in a Context-Appropriate Way: Queer Narratives in an EFL College Classroom in Japan', Journal of Language, Identity \& Education 5, 1: 51-66.

Pavlenko, Aneta. 2004. 'Gender and sexuality in foreign and second language education: Critical and feminist approaches', in: Bonny Norton and Kelleen Toohey (eds.), Critical pedagogies and language learning. Cambridge: Cambridge University Press, 53-71.

Pawelczyk Joanna, Graf Eva M. 2011. "Living in therapeutic culture: Feminine discourse as an agent of change.” In: Majstorović, D.; Lassen, I. (eds.) Living with Patriarchy. Discursive Constructions of Gendered Subjects Across Cultures. Amsterdam: John Benjamins, 273-302.

Pawelczyk, Joanna, Łukasz Pakuła and Jane Sunderland. 2014. 'Issues of power in relation to gender and sexuality in the EFL classroom -- An overview', Journal of Gender and Power 1, 1: 49-66.

Queen, Robin. 2006. 'Heterosexism and/in language', in: Edward Keith Brown (ed.), Encyclopedia of Language \& Linguistics. Amsterdam: Elsevier, 289-292.

Renold, Emma. 2005. Girls, Boys and Junior Sexualities: Exploring Childrens' Gender and Sexual Relations in the Primary School. London: Routledge. 
Ripley, Matthew, Eric Anderson, Mark McCormack and Ben Rockett. 2012.

'Heteronormativity in the University Classroom Novelty Attachment and Content Substitution among Gay-friendly Students', Sociology of Education 85, 2: 121-130.

Rogers, Wendy Stainton and Rex Stainton Rogers. 2001. The psychology of gender and sexuality: an introduction. Maidenhead: Open University Press.

Rosario, Margaret, Eric W. Schrimshaw and Joyce Hunter. 2012. 'Risk factors for homelessness among lesbian, gay, and bisexual youths: A developmental milestone approach', Children and Youth Services Review 34, 1: 186-193.

Rothing, Ase. 2008. 'Homotolerance and heteronormativity in Norwegian classrooms', Gender and Education 20, 3: 253-266.

Schmitz, B. (1975) Sexism in French language textbooks. In: Lafayette, R. C. (ed.), The cultural revolution in foreign language teaching. Skokie, Ill.: National Textbook Co., p. 119-130.

Sullivan, Nikki. 2003. A critical introduction to queer theory. New York: New York University Press.

Sunderland, Jane, Maire Cowley, Fauziah Abdul Rahim, Christina Leontzakou and Julie Shattuck. 2002. 'From Representation Towards Discursive Practices: Gender in the foreign Language Textbook Revisited' , in: Lia Litosseliti and Jane Sunderland (eds.), Gender Identity and Discourse Analysis. Amsterdam: John Benjamins Publishing.

Świerszcz, Jan (ed.). 2012. Lekcja równości: postawy i potrzeby kadry szkolnej i młodzieży wobec homofobii w szkole [Lesson of equality: The attitudes and needs of teachers and students towards homophobia in school]. Warszawa: Kampania Przeciw Homofobii.

Toomey, Russell B., Jenifer K. McGuire and Stephen T. Russell. 2012. 'Heteronormativity, school climates, and perceived safety for gender nonconforming peers', Journal of Adolescence 35, 1: 187-196.

Weeks, Jeffrey. 2010. Sexuality. (3rd edition.) Routlege.

Żukowski, Tomasz (ed.). 2004. Szkoła Otwartości [School of openmindedness]. Warszawa: Stowarzyszenie 'Otwarta Rzeczpospolita'.

\section{Textbooks referred to:}

Nolasco, Rob and David Newbold. 2007. New English Zone 3. Student's Book. Podręcznik do szkoły podstawowej. Oxford: Oxford University Press.

Arthur, Lois and Rob Nolasco. 2007. New English Zone 3. Workbook. Zeszyt ćwiczeń. Oxford: Oxford University Press. 
Newbold, David and Rob Nolasco. 2007. New English Zone 3. Teacher's Book. Oxford: Oxford University Press.

Evans, Virginia and Jenny Dooley. 2010. Starland 3. Student's Book. Newbury: Express Publishing.

Evans, Virginia and Jenny Dooley. 2010. Starland 3. Workbook 7 Grammar. Newbury: Express Publishing.

Evans, Virginia and Jenny Dooley. 2010. Starland 3. Teacher's Book. Newbury: Express Publishing. 